\title{
TTR
}

Traduction, terminologie, re?daction

\section{Entre les langues : Between de Christine Brooke-Rose}

\section{Sherry Simon}

Volume 9, numéro 1, 1er semestre 1996

Le festin de Babel

Babel's Feast

URI : https://id.erudit.org/iderudit/037238ar

DOI : https://doi.org/10.7202/037238ar

Aller au sommaire du numéro

\section{Éditeur(s)}

Association canadienne de traductologie

ISSN

0835-8443 (imprimé)

1708-2188 (numérique)

Découvrir la revue

Citer cet article

Simon, S. (1996). Entre les langues : Between de Christine Brooke-Rose. TTR, 9(1), 55-70. https://doi.org/10.7202/037238ar

\section{Résumé de l'article}

Entre les langues : Between de Christine Brooke-Rose- Dans Between de Christine Brooke-Rose, il est question d'une interprète de conférence, qui vit dans l'espace entre les langues. Cet état est mimé par l'écriture, qui elle aussi se promène entre les lieux, les langues et les appartenances, défiant souvent les conventions syntaxiques et narratives. S'agit-il d'un roman moderne ou postmoderne ? L'héroïne du roman annonce la " culture traductionnelle " à venir.

Tous droits réservés ( $\mathrm{TTR}$ : traduction, terminologie, rédaction — Les auteurs, Ce document est protégé par la loi sur le droit d'auteur. L’utilisation des 1996 services d’Érudit (y compris la reproduction) est assujettie à sa politique d'utilisation que vous pouvez consulter en ligne.

https://apropos.erudit.org/fr/usagers/politique-dutilisation/ 


\title{
Entre les langues: Between de Christine Brooke-Rose
}

\author{
Sherry Simon
}

\begin{abstract}
Und since man spricht sehr little Deutsch unlike un clever sweet half born and bred on Pumpernickel, man denkt in eine kind of erronish Deutsch das springt zu life feel besser than echt Deutsch. Und even wenn man thinks AUF Deutsch wann man in Deutschland lives, then acquires it a broken up quality, die hat der charm of my clever sweet, meine deutsche madchen-goddess, the gesture and the actions all postponed while first die Dinge and die Personen kommen. As if languages loved each other behind their own facades, despite alles was man denkt daruber davon dazu. As if words fraternised silently beneath the syntax, finding each other funny and delicious in a Misch-Masch of tender fornication, inside the bombed out hollowed structures and the rigid steel glass modern edifices of the brain. (Between, Christine Brooke-Rose, pp. 53-54)
\end{abstract}

La pluralité des langues hante l'écriture postmoderne, comme elle a profondément marqué l'écriture de la modernité. Les croisements de langue dans le texte, la fascination de la langue étrangère, sont signes de la fragmentatiơn et de l'interpénétration des identités culturelles. En interrogeant les imaginaires de l'appartenance, en faisant état de dissonances et d'interférences textuelles, le texte 
plurilingue fait état des bouleversements socio-démographiques et conceptuels de notre époque, et fait appel à de nouveaux modes de symbolisation.

Le caractère transnational des expressions culturelles du monde postcolonial, les textes hvbrides, sont en passe de devenir des objets légitimes, plutôt qu'exceptionnels, ${ }_{2}$ de la linguistique et de la littérature $\mathrm{t}^{\mathrm{t}}$. Rushdie est-il un auteur indien ou anglais ? Kundera, un Tchèque ou un Français ? Le bilinguisme littéraire, plutôt que d'être une entrave à la production, est reconnu comme source d'innovation et d'interférence créatrices. Régine Robin montre comment de Kafka à Celan, de Conrad à Kerouac, de Nabokov à Beckett en passant par Georges Perec, Elias Canetti, et d'autres, la conscience de la "langue perdue " mais aussi la fascination de l'étrangeté linguistique anime le texte moderne (Robin, 1993). Claudio Magris, évoquant le développement singulier de la modernité italienne à Trieste, parlera d'une " littérature des frontières " (Ara, 1991); Édouard Glissant pour sa part explorera " la poétique de la relation $n$ telle qu'elle se développe dans l'espace créole des Antilles (Glissant, 1993). Le rapport à la langue étrangère, fondé par des circonstances de bilinguisme personnel, souvent transformées en relations fantasmatiques, nourrit de façon șingulière la litterature du $20^{\circ}$ siècle.

Les récits de l'immigration et de l'exil, les æuvres qui racontent les expériences de déplacement et de re-localisation

1. Par « productions transnationales», j'entends toute une gamme de stratégies de mise en ceuvre de l'hétérogénéitéculturelle: sur le plan thématique (immigration, migrations), sur le plan des références culturelles ou des formes (le théâtre et la performance transculturelle), ou sur le plan des langues ou de l'identité des participants. Le théâtre de Robert Lepage fournit un corpus exemplaire dans ce contexte, particulièrement par le jeu entre plusieurs langues dans ses pièces. Voir Jill McDougall, Performing Identities on the Stages of Quebec, à paraître chez Peter Lang, et S. Simon (1994). 
propres au contexte postcolonial, sont peuplés de l'imaginaire de diverses langues. Ainsi, les littératures issues des " deuxièmes gẻnérations " d'immigrants dans les pays occidentaux jouent volontiers d'une pluralité de codes, exprimant ainsi le désarroi ou encore la jouissance que leur inspire cet état d'hybridité culturelle. L'expérience de l'enracinement dans l'hétérogène, que ce soit celle des " beurs » en France ou des « chicanos » aux Ėtats-Unis, est à l'origine de pratiques littéraires où se manifeste le choc des idiomes. (Fusco, 1995) Pour ce qui est du contexte québécois! des textes de fiction mettent l'accent sur la mobilité des frontières de l'identité culturelle québécoise. On peut parler dans certains cas de proetdés de création interlinguale (ou de traduction inachevée qui ont pour résultat ta mamrestation " d'effets de traduction » dans le texte qui prennent la forme d"un vocabulaire disparate, d'une syntaxe inhabituelle, ou d'un dénuement " déterritorialisant ». Ces éléments d'interférence créent une certaine ouverture ou " faiblesse » sur le plan de la maîtrise linguistique et du tissu de références auxquelles s'affilie le texte (Simon, 1994).

Plutôt, cependant, que de simplement constater l'accélération des phénomènes de " transnationalisation 》 des productions culturelles du monde contemporain, la critique doit pouvoir comprendre bes contextes historiques et culturels qu'elles expriment ansi que les valeurs qu'elles mettent en jeu. C'est dans cette optique que je propose une lecture de Between, roman de Christine Brooke-Rose, écrit en 1968. Texte traversé par une pluralité de langues, écrit sous forme de collage, Between met en mots l'expérience vertigineuse de l'interprète de conférence - choix de carrière né seulement après la Deuxième guerre mondiale avec la création du réseau d'organismes internationaux. Mais si son état bilingue donne à l'interprète des privilèges énormes (et surtout celui de pouvoir voyager un peu partout a travers le vaste monde), il la condamne aussi à continuer a porter les blessures de la guerre, à vivre une existence divisée, entre la solitude et le "glamour » de la carrière, entre le désir et la peur. 


\section{In Transit}

Between de Christine Brooke-Rose est un roman écrit principalement en anglais et publié à Londres en $1968^{2}$, En tant que professeure et écrivaine, Brooke-Rose a subi l'inftuence de la pensée française, et en particulier celle du Nouveau Roman de Nathalie Sarraute et d'A. Robbe-Grillet. Elle est devenue l'un des rares auteurs (peut-être mềme le seul) de langue anglaise de cette époque à pratiquer une écriture wóritablement expérimentale dans la foulée de la pratique francaise. Chacun de ses romans est fondé sur une figure de l'écriture, sur un mécanisme générateur, à la manière des « machines d'écriture » de Raymond Roussel. Chaque texte propose un discours fondé sur un jeu de règles précises, et Between ne fait pas exception.

Il est question dans Between d'une interprète de conférence, français-allemand. Dans les interstices du texte on retrouve les bribes de sa biographie que l'on arrive à reconstituer peu à peu: elle est née en France d'un père allemand qui disparaît après sa naissance; sa mère l'envoie dans la famille de son père en Allemagne juste avant la guerre pour poursuivre ses études; l'appendicite l'empêche de retourner en France au moment où la guerre est déclenchée. Elle ne retrouvera plus sa mère, se mariera avec un Anglais plus âgé qu'elle, se séparera du mari, aura une relation frivole avec un camarade interprète Siegfried, qui finira par se marier avec quelqu'un d'autre mais restera son ami intime, et aura par la suite une aventure malheureuse avec un spécialiste de la littérature provençale. Durant de nombreuses années elle entretient une correspondance avec le Vicariatus Urbis Tribunal Romana en vue

2. Quelques données biographiques: Née en 1923 d'un père anglais et d'une mère suisse, $C$. Brooke-Rose a fait des études en Suisse, en Belgique et en Angleterre; elle a eu donc une vie familiale et une éducation plurilingues. Elle a fait un doctorat sur le moyen anglais en 1954 a Londres, a fait du journalisme culturel pour des publications prestigieuses, et en 1968 est devenue professeure à Paris VIII, prenant sa retraite en 1987 pour s'établir en Provence. 
d'obtenir l'annulation de son mariage; elle devra produire une déposition détaillée et recevra trois rapports successifs des autorités écclesiastiques (pp. 41-42). Il est question aussi de l'achat et ensuite de la vente d'une maison de campagne dans le Wiltshire in Angleterre, d'une visite en France, et enfin d'un voyage nostalgique en Allemagne.

Le texte est agencé à la manière d'un collage, la trame narrative se résumant à l'énumération de lieux et de situations qui se juxtaposent et se surimposent: congrès international de démographes à Copenhague, congrès sur l'écrivain et la communication à Prague, des archéologues à Istanbul, des sémiologues à Dubrovnik, des acuponcteurs en Italie, et ainsi de suite à Budapest, Sofia, Moscou, Amsterdam, Paris, Londres, New York ... Voyages d'affaires assortis d'excursions touristiques, en compagne de Signor Ingegnere Giovanni-Battista di Qualcosa, Erich von Irgendtwas ou Comrade Pan Bogumil Somethingski. Les exigences de son métier l'obligent à voyager d'un lieu à l'autre, d'une langue à l'autre:

the eyes closed to watch the words as they pass through the distant brain way up, steadily in phrases well-formed almost in advance to hit the German nail on the.Erench pinpoint. Unless alternatively concision shrinks the statistics like angels to a pinhead and the pinhead pricks the Gallic nuance which escapes like gas and lingers far behind the inklings of the few depending on the speaker's nationality in French, Italian for instance, Polish or verbose, depending on the theme the time the place the climate, whether canyons create new problems as in politics and pamphlets full of Kulturstatten-Places of Cultural Interest-Curiosités culturelles-Curiosità CulturaliCentros culturales. (p. 88)

L'enchaînement est toujours imprévisible. La discontinuité des lieux est mimée par une syntaxe qui respecte les convenances de la grammaire mais met le sens en dérive. Une phrase peut commencer dans un lieu, dans une langue, et terminer dans un lieu et un idiome tout autre: 
Between the dawn and the non-existent night the body stretches out its hundred and twenty ribs or so towards the distant brain way up beyond the yellow curtain that divides the ordinary from the better and no doubt behind a little door.

- Mesdames messieurs. Air France vous souhaite la bienvenue à bord de cet énorme problème devant lequel cependant le langage flows into the ear and comes out into the mouthpiece over waves and on into the ears of the multitudes or so in simultaneous German. (p. 10)

Dans Between, l'expérimentation repose sur un mélange de langues naturelles différentes (surtout l'anglais, le français et l'allemand, mais aussi le roumain, le grec, etc.), mais aussi sur les croisements de discours tels que les langages pseudo-scientifiques des congrěs. Ies platitudes de la diplomatie internationale, le bavardage des yoyageurs. Le caractère đynamique de ces croisements est intensifié par l'absence du verbe " être ». Il s'agit là d'une contrainte imposée par l'auteur, qui espérait ainsi donner à l'état de la protagoniste un caractère actif et mouvementé?

3. Explication de l'auteure: « I wanted to get the constant sense of movement. She's always on the go, she never knows where she wakes up. It's amazing how once you don't use the verb 'to be' (and it's extremely difficult not to), you're forced to find another verb, and it's usually an active verb. This gave a sense of constant movement. The other reason whas the other sense of the verb 'to be', the existential sense - she just doesn't know who she is, she is always translating from one language to another and never quite knows to which language she belongs, and in fact she belongs to three because she's German, French, and married to an Englishman, or divorced from him, I forget the details. And of course, it's writing in English, so the basic convention is English. The other languages are used to show that she doesn't know every language in the world: They block the text, rather like the ideograms in Pound. Things like 'exit' in Polish, people don't necessarily recognize it. So I'm playing with disorientation, the 
Le titre du livre fournit la figure dominante du récit. ENTRE. " Entre " est en même temps un lieu of un état. La première phrase du roman situe l'hérö̈ne " entre les énormes ailes de l'avion " (" Between the enormous wings the body of the plane stretches its one hundred and twenty seats or so in threes on either side towards the distant brain way up, behind the dark blue curtain and again beyond no doubt a little door " (p.1)) mais en même temps dans l'état d'esprit du voyage qui est d'être dans un " entre temps »: "Between doing and not doing the body floats. " (p. 1)

Mais cet « entre » est également l'espace du " peut-être ", de l'" ou bien ". S'agit-il d'un avion où les femmes et les hommes sont assis séparément ou d'un avion où " les chromosomes se mêlent joyeusement ", d'un avion à réaction ou d'un avion à hélices; verra-t-on apparấtre bientôt une femme de chambre (" bright or elderly sour ") ou " a smooth floor-steward in white " (pp. 1-2). Cette suite de possibles établit le temps du récit comme un temps indéterminé. semblable à la temporalité indéterminée d'un roman comme la Québécoite de Régine Robin, écrit au conditionnel. Comme ce dernier roman, Between présente un conscience éclatée au moyen d'une pluralité de discours. Alors que Régine Robin fait état d'une traversée et de la tentative (qui s'avère impossible) d'un nouvel enracinement, la protagoniste de Christine Brooke-Rose est plutôt condamnée à une pérégrination sans but et sans fin. " A woman of uncertain age and uncertain loyalties. " (p. 122) La médiation langagière est évidemment le lieu central où s'élabore cette figure, puisqu'il s'agit d'interprétation. La conscience de la protagoniste est un carrefour où les langues se rencontrent. Mais le texte va bien au-delà de cette médiation particulière pour faire état des multiples variantes de l'interstitiel: en voyage la protagoniste est

disorientation of travel, we've all had it. And the doublereading jokes, too, are familiar. If you read a word in your own language, it can come out like a pun: 'lecheria', in Spanish, for example, which means milk shop, but of course, she reads it as 'lechery'. " (" A Conversation with Christine Brooke-Rose ", Ellen G. Friedman and Miriam Fuchs, p. 84) 
entre sommeil et veille, entre l'air des hauteurs et la matière terrienne ( $~$ The body floats in a quiet suspension of belief and disbelief... the ship bumps down the steps of air " (p. 12) entre ironie et nostalgie, entre mémoire et anticipation ( $~$ Tomorrow and tomorrow creeps into this petty place among the potted palms $)$ (p. 119), entre les monuments de l'histoire et la banalité du présent, entre la pauvreté du Tiers-monde et la richesse du monde développé, entre l'incertitude et

the vulgar need for dogmas and static images, banalising the great and ancient myths of fall, descent and rise into innumerable instructions that translate time space death rebirth into a narrow channel of salvation according to those instructions only (p. 106)

entre la passion et la peur (dans la solitude de la chambre d'hôtel elle est constamment harcelée par la crainte « the fear of something else not ordered, Haben Sie noch ein Wunsch ? » p. 7).

A la fragmentation narrative et linguistique s'ajoute une fragmentation spatiale, qui se joue dans l'accumulation et la juxtaposition des lieux, chambre d'hôtels et salles de conférences, qui se succédent sans qu'il y ait une progression ou un sens à cette succession. Cette esthétique du disparate reproduit l'état de dispersion intérieure de la protagoníste, alors qu'elle poursuit sa fuite en avant, allant de rencontre à rencontre, sans que les liens s'établissent. (". Only connect ", a dit E. M. Forster: ici les liens affectifs ne sont jamais pleinement achevés.)

\section{Fragments et valeurs}

Alors se pose la question de la valeur de cet « entre ». Il sert d'abord à véhiculer une critique tranchante des lieux communs de l'internationalité. Que font les membres des nombreuses commissions et équipes internationales, sinon échanger des platitudes? 
Paris as Headquarters of simultaneous interpreters and international organisations for the advancement of peace common markets intercontinental missiles agricultural aid economical social cultural irrigation for refugees... husbands lovers wives mistresses of many nationalities who help to abolish the frontiers of misunderstanding with frequent changes of partners loyalties convictions, free and easily stepping over the old boundaries of conventions, congresses, commission, conferences to which welcome back Liebes. (p. 43)

Et que créent les nouveaux moyens de l'information sinon une culture de la médiocrité ?

In fondo a sinistra the men in the cafe sit transfixed by the flickering local variation in the presentation of opposite viewpoints on every aspect of an instant world through faceless men who have no doubt acquired faces for them as their archpriests of actualita that zooms flashcuts explodes to OMO! Da oggi con Perboral! Lava ancora più bianco! Gut-gut. Più bianco than what? We live in an age of transition, perpetually between white and whiter than white. (p. 25)

Mais le savon, même annoncé d'un coin à l'autre de l'Europe, ne peut pas enlever les traces de la haine et des divisions laissées par la guerre.

You can't Persil-schein your German layers that easily meine Liebe. Let's fact it you destroy. All that suffering stuff you enjoy it nicht wahr nicht wahr? Aber man achtet nicht darauf. As if languages loved each other beneath their own façades, despite alles was man denkt daruber davon dazu. Then acquires alles a broken up quality, die hat der charm of my clever sweet, my deutsche madchen-goddess, the gesture and the actions all postponed while first die Dinge und die Personen kommen. Aber woaus und woein kommen die Personen? (p. 123)

Dans les insinuations de Siegfried il y a la suggestion que les langues ne sont pas innocentes. Ainsi les pouvoirs de l'interprète 
sont-ils sujets à soupçon. Notre héroïne a-t-elle en fait travaillé pour les Allemands durant les dernières années de la guerre ? Nous ne le saurons pas.

La liberté permise par l'espace « entre » les langues et les cultures, est-eIle en fait une liberté vide ?

Have you anything to declare such as love desire ambition or a glimpse that in this air-conditioning and other circumstantial emptiness freedom has its sudden attractions as the body floats in willing suspension of responsibility to anyone, stretching interminably between the enormous wings towards the distant brain beyond the orange curtain and behind, no doubt, the little door. (p. 28)

Où peut-on trouver l'authenticité des sentiments, la vêrité de la culture?

Which represents reality the old towns like museums visited on conducted tours or the modern hotels we stay in all alike? (p. 25)

L'《 entre », enfin, est aussi le lieu qui permet que le sens se produise. Brooke-Rose fait allusion à la théorie saussurienne de la valeur oppositionnelle du sens, en rappelant que l'opposition peut se créer entre un terme marqué et une absence.

Et comme l'a si bien dit Saussure, la langue peut se contenter de l'opposition de quelque chose avec rien. The marked term on the one hand, say, the feminine, grande, the unmarked on the other, say, the masculine, grand. Mais notez bien que le non-marqué peut dériver du marqué par retranchement, by subtraction, par une absence qui signifie. Je répète, une absence qui signifie eine Abwesenheit die simultaneously etwas bedeutet. (p. 32)

Quelle est cette absence qui signifie ? Celle que porte le corps de la femme, selon Freud ? Le verbe être qui ne paraîtra pas dans le roman? Le père de notre hérö̈ne, qui, comme elle, reste sans nom ? 
"Between ", l'état d'être entre. se révèle être à la fois un lieu et l'absence d'un lieu, une sorte de bonheur et la conscience du désastre. Même le désir d'amour finira par s'étioler. Alors que la langue s'exalte quand la rencontre amoureuse se propose:

So the white gladiolus explodes in letter after letter in a language that finds itself delicious and breeds plants or parts of plants inside the seven-terraced tower undoing the magic wall of defence anticlockwise... E allora the languages fratemise in a frenzy of fornication by airmail par avion via aerea Luftpost... (p. 148)

elle perd ses moyens quand il s'agit d'un véritable contact de corps.

Le glaieul a fichu le camp in a language that finds itself delicious par avion but force-lands on a clay-like sea you could cut with a knife pick up in handfuls. (p. 158)

Il paraît qui lui, l'amant spécialiste du provençal, est marié; elle, " a desiccated alleinstehende Frau ", doit ramasser les morceaux d'une vie brisée, " in quiet suspension of anger between total indifference and a mild desire to pick up the broken bits » (p. 159).

"What difference would it make? " La question réapparaît comme un leitmotif dans le roman. De quelles differences s'agit-il ? Celles qui agitent le rêve d'un Babel joyeux et celles qui prolifèrent dans le cauchemar de Jean Baudrillard évoqué par Susan Rubin Suleiman, \& a world of simulacra where all real distinctions are abolished and we are left only with 'the simulated generation of difference' " (Suletmm, pp. 125-126).

Brooke-Rose's alone-standing woman may stand (perhaps not too far from Deleuze and Guattari's eternal bachelor ?) as one emblem of our ambiguous present, or what some have called (applauding or decrying, it depends) our postmodernity. (Suleiman, pp. 126-127) 
Cette femme rappelle également une figure qui est de facture plus récente. Le " between " de Christine Brooke-Rose ressemble mutatis mutandis à l'état interstitiel évoqué par Homi Bhabha quand il décrit l'identité culturelle du migrant postcolonial, son caractère " transnational et traductionnel ». Le traumatisme et le désarroi qu'il décrit en évoquant " la culture traductionnelle " s'appliquent parfaitement à cette femme dont les repères affectifs sont aussi instables que son ancrage linguistique. Ainsi l'état d'être " entre " n'est plus un privilège réservé à la mince couchêe aristocrate de fonctionnaires d'organismes internationaux; il s'applique également à la grande masse des migrants qui aujourd'hui sillonnent le globe. Comme l'héroïne de Between, la pensée du migrant nous rappelle que l'étrangeté des langues est ce qui fait que le transfert de sens, l'intégration du nouveau dans l'ancien, de l'exotique dans le familier, du colonial dans le métropolitaín, ne peut pas être complet, que le produit sera toujours excédentaire par rapport aux éléments de départ.

Les transactions linguistiques, en d'autres termes, sont un fait permanent de notre état de société et colorent l'ensemble des productions culturelles. Il se crée, du fait de l'accélération des communications et des déplacements, et de la généralisation des échanges culturels, ce que l'on peut appeler une culture de la traduction. Appartenant en premier lieu aux nombreux immigrants, réfugiés, et aux migrants de notre époque qui ont à traverser des frontières, cet espace culturel tend à devenir aussi celui de tout " être traduit ${ }^{4}$ ", autant dire tout citoyen de la culture postmoderne. La culture de la liminalité, prenant la forme des idiomes mixtes, en vient à exprimer l'instabilité de toute identité.

4. « Having been borne across the world, we are translated men. It is normally supposed that something always gets lost in translation; I cling, obstinately to the notion that something can also be gained " (Salman Rushdie, Imaginary Homelands, London, Granta Books, 1991, p. 17). 
C'est ce " lieu » de la culture que Bhabha repère et explore dans The Location of Culture (1994), et qui est déjà présent dans Between. La culture n'est pas à saisir dans une logique de la " diversité « (la culture comme un objet de savoir empirique, comme une totalité close, une " bulle " qui enveloppe les comportements, selon les visions les plus éculées du multiculturalisme), mais dans une logique de la " différence ${ }^{5}$. Quand Bhabha évoque donc une " culture transnationale et traductionnelle n, il fait référence à un lieu de création culturelle. Cet espace de négociation définit une subjectivité, du transactionnel et du performatif. Il s'agit de repenser l'espace de la globalité non pas comme une " pluralité démographique ", un ensemble d'identités catégorisables, mais d'étudier les processus de transformations identitaires à la frontière, là où se déroulent des processus de traduction qui ne peuvent jamais être menés à terme, une fois pour toutes.

Au lieu de considérer ces espaces liminaires et transitionnels comme imparfaits et donc inférieurs, il faudra y voir le lieu de la construction de nouveaux signes d'identité, des lieux de collaboration et de contestation essentiels à la définition de la société elle-même. L'espace interstitiel de la traduction acquiert ainsi une importance proprement fondatrice : il porte la responsabilité de dire le sens de la culture, sens qui s'établira comme non-coöncidence, disjonction et distance. La traduction prend le devant de la scène. "It is the inter - the cutting edge of translation and negotiation, the in-between space - that carries the burden of the meaning of culture. " (Bhabha, p. 2)

5. "The representation of difference must not be hastily read as the reflection of pre-given ethnic or cultural traits set in the fixed tablet of tradition. The social articulation of difference, from the minority perspective, is a complex, on-going negotiation that seeks to authorize cultural hybridities that merge in moments of historical transformation. " (Bhabha, 1994, p. 2) 
Applaudie ou critiquée, l'internationalisation des thèmes et des styles est désormais un fait marquant des productions culturelles. Enraciné dans le traumatisme de l'histoire européenne, Between annonce la "culture de la traduction " à laquelle s'abreuve l'imaginaire contemporain.

\section{Références}

ARA, Angelo et Claudio Magris (1991). Trieste, une identité de frontière. Traduit de l'italien par Jean et Marie-Noelle Pastureau. Paris, Seuil.

ARTEAGA, Alfred, dir. (1994). An Other Tongue. Nation and Ethnicity in the Linguistic Borderlands. Durham, Duke University Press.

BHABHA, Homi (1994). The Location of Culture. Londres et New York, Routledge.

BAKHTINE, Mikhail (1978). Esthétique et théorie du roman. Traduit par Daria Olivier. Paris, Gallimard.

BERMAN, Antoine (1984). L'Épreuve de l'étranger. Culture et traduction dans l'Allemagne romantique. Paris, Gallimard.

(1985). Les Tours de Babel. Essais sur la traduction. Mauvezin, Trans-Europ-Repress.

BROOKE-ROSE, Christine (1968). Between. Londres, Michael Joseph.

(1989), pp. 55.71.

(1989). « Illiterations 》, in Friedman, E.G. et M. Fuchs

FORSTER, Leonard (1970). The Poet's Tongues. Multilingualism in Literature. Cambridge University Press. 
FRIEDMAN, E.G. et M. FUCHS (1989). Breaking the Sequence: Women's Experimental Fiction. Princeton, New Jersey, Princeton University Press.

FRIEDMAN, E.G. (1995). « A Conversation with Christine BrookeRose ", in E. G. Friedman et Richard Martin, dir. (1995). Utterly Other Discourse. Normal, IL, Dalkey Archive Press.

FUSCO, Coco (1995). English is Broken Here. Notes on Cultural Fusion in the Americas. New York City, The New Press.

GLISSANT, Édouard (1993). " Entretien: l'imaginaire des langues ", Études françaises, 28, 2/3, automne.

PRATT, Mary Louise (1991). " Arts of the Contact Zone ", Profession 91, Publication de la Modern Language Association, New York.

ROBIN, Régine (1983). La Québécoite. Montréal, Québec/ Amérique.

(1984). L'Amour du yiddish; écriture juive et sentiment de la langue (1830-1930). Paris, Éditions du Sorbier.

(1988). Kafka. Paris, Belfond.

(1990). Le roman mémoriel. Longueuil, Le Préambule.

SABIN, Margery (1987). The Dialect of the Tribe, Speech and Community in Modern Fiction. New York, Oxford University Press.

SARKONAK, Ralph et Richard Hodgson (1993) "Writing... in Stereo: Bilingualism in the Text ", Visible Language, 27, 1/2, Winter/Spring.

SHELL, Marc (1993). Babel in America; or, the Politics of Language Diversity in the United States. Critical Inquiry, vol. 20, 
SIMON, Sherry (1994). Le Trafic des langues. Traduction et culture dans la littérature québécoise. Montréal, Boréal.

SPIVAK, Gayatri Chakravorty (1993). Outside in the Teaching Machine. New York et Londres, Routledge.

STEINER, George (1975). After Babel. Londres, Toronto, Oxford University Press.

SULEIMAN, Susan R. (1995). « Living Between, or the Lo $n / v$ eliness of the Alleinstehende Frau ", in Ellen G. Friedman et Richard Martin, dir. (1995), pp. 124-127.

RÉSUMÉ: Entre les langues : Between de Christine Brooke-Rose - Dans Between de Christine Brooke-Rose, il est question d'une interprète de conférence, qui vit dans l'espace entre les langues. Cet état est mimé par l'écriture, qui elle aussi se promène entre les lieux, les langues et les appartenances, défiant souvent les conventions syntaxiques et narratives. S'agit-il d'un roman moderne ou postmoderne ? L'héroïne du roman annonce la " culture traductionnelle » à venir.

ABSTRACT: Between languages : Between by Christine BrookeRose - Between by Christine Brooke-Rose is an experimental novel which, like its heroine, a conference interpreter, is in constant movement between languages, places and identities. The space "between" suggests something of the "translational culture" which, according to Homi Bhabha, is increasingly the culture of our present.

Sherry Simon: Département d'études françaises, LB-631-10, Université Concordia, 1455 boul. de Maisonneuve Ouest, Montréal, Québec H3G 1M8, CANADA 